Relations industrielles

Industrial Relations

\title{
Labour-Management Committees
}

Volume 4, numéro 8, avril 1949

URI : https://id.erudit.org/iderudit/1023520ar

DOI : https://doi.org/10.7202/1023520ar

Aller au sommaire du numéro

Éditeur(s)

Département des relations industrielles de l’Université Laval

\section{ISSN}

0034-379X (imprimé)

1703-8138 (numérique)

Découvrir la revue

Citer cet article

(1949). Labour-Management Committees. Relations industrielles / Industrial Relations, 4(8), 75-76. https://doi.org/10.7202/1023520ar

Tous droits réservés @ Département des relations industrielles de l’Université Laval, 1949
Ce document est protégé par la loi sur le droit d'auteur. L’utilisation des services d'Érudit (y compris la reproduction) est assujettie à sa politique d'utilisation que vous pouvez consulter en ligne.

https://apropos.erudit.org/fr/usagers/politique-dutilisation/ 


\section{LABOUR - MANAGEMENT COMMITTEES ${ }^{\circ}$}

It is now several decades since various systems have been extolled and even experimented with in an attempt to lessen the subordination that the worker feels weighing on him more and more as the enterprise increases in importance.

Already in the last century, British manufacturers had created «Conciliation Councils》 in their factories, and a Belgian engineer, who had seen them in operation, had tried to introduce them here in the Eighties. In the United States, at the beginning of the 20th century, if not before, some employers had created Company unions, i.e. factory unions of which the committee had also the task of settling the many incidents which adorn the day to day existence of large industrial establishments. But in both cases, the idea of the employers was to eliminate a newly-formed professional group, in taking away from it the opportunities to intervene in favour of the personnel or better still to prevent it from even getting a start in life.

During the first World War, following the recommendations of the Reconstruction Commission presided by Whitley, one of the leaders of industry, the works committees in an enterprise played an important part in British industrial relations. They were based at this time on the associations of employers and labour unions. However, from 1925 on the two parties gradually lost interest in the new institution and returned to the «shop stewards» movement more in line with their traditions.

The real committees of enterprise came, in almost all of Central Europe, from the revolutionary movements that followed the defeat of 1918. Although their principal objective has been the recovery of the national economy, they have been considered as a great victory for organized labour and, because of this, they have often met with distrust, if not hostility, from employers. The severe depression, which hit these countries, as it did others, after 1930, led the Committees to take up a position of retreat, which caused disaffection among the workers.

After the second World War, committees of enterprise were installed by law in several countries. In Europe alone we might mention France, Austria, Italy, Poland, Czechoslovakia and Hungary. In the Scandinavian countries, the law did

(1) Ministère du Travail et de la Prévoyance Sociale de Belgique, Revue du Travail, Bruxelles, 49e année, No 12, décembre 1948, pp. 1053-1055. (Translation). not interfere but a national collective agreement in 1946 regulated the function of «boards of enterprise $\gg$, very similar to the committees.

In England, on the other hand, where the labour movement has been solidly implanted for a longer time than elsewhere and where the Labour Party, in power for the last three years, has accomplished many far-reaching reforms, there is no question of a law on committees of enterprise and in the German-speaking part of Switzerland, the labour unions give a rather cool reception to the propositions of the Romanic unions, inspired by what is going on in Western Europe. This attitude cannot be explained by a lack of willingness on the part of the workers to participate in the management of enterprises, but rather by the anxiety to retain union control on eventual participation in the management of enterprises.

In regard to the form of the committees of enterprise various systems are in operation. In France and in Holland as under our law, the head of an enterprise may be alone a member of the committee or it may be other persons chosen by it, but without there being equal representation. In the countries of Central Europe, management was absent, the committee meeting with it or its representatives when it judged it to be necessary.

Usually, representatives of the personnel were elected by all the personnel; but it sometimes happened that there were several distinct electoral colleges, in order to insure representation to different categories, for example to the employees.

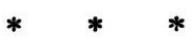

Union interference in the constitution or operation of the committees is quite varied. In several countries, the candidates had to be, between the two wars, as under our law, presented by the unions. It is still the case in France for the first vote. Elsewhere, it is only necessary to belong to the union to be a candidate.

In Hungary and in Germany, before the dictatorial form of government and in France at present, the union representatives attend the meetings of the committees with the right of discussion but without that of voting. 
The attributions of the committees are more or less extended, in accordance with the real power with which it is desired to entrust them and, on the other hand, in accordance with the mission that it is wanted to reserve for the unions.

In respect to working conditions, these usually include the application of rules concerning hygiene and workers' safety, suggestions towards these ends, discussion of shop rules and the direction of possible social institutions. Consultation in cases of hiring and discharge is frequent but without being general.

Committees of enterprise very seldom intervene in collective conflicts and in collective agreements which are a domain reserved to the unions.

On the other hand, all laws instruct the committees of enterprise to gather and transmit all suggestions to improve the efficiency of an enterprise. The furnishing of certain accounting records is prescribed almost everywhere, but the nature of the records and the enterprises under this obligation vary from one country to another. The designation of accountants to aid the committee in the examination of these records is only provided for in France besides our own country. In a general way, the committees have only an advisory part to play in economic matters. They leave to the employer the responsibility of conducting the business.

The common characteristics of committees of enterprise may be formulated as follows: the committee is composed of representatives elected by the different categories of the personnel, as proposed by the union organizations; it does not interfere with the management of the business, but it disposes of advisory attributions regarding efficiency, organization and general progress of the enterprise, apprenticeship and professional training, hiring and discharge; it intervenes in a more or less important way in the administration of the welfare and social organizations of the enterprise, and in the application of the rules relating to working conditions, hygiene and workers' safety.

\section{SALARY TRENDS OF EMPLOYEES OF THE WHOLESALE FOOD TRADE OF QUEBEC}

\section{RAYMOND GAGNÉ}

A statistical survey has been made recently in the Wholesale Food Trade of the City of Quebec and surrounding district.

The end in view was to establish a statistical relation between the salaries fixed by the decrees under the Collective Agreement Act and the salaries paid by the employers. We have deviated slightly from this end because the salaries decreed were too rigid to calculate averages which should have been then compared with the averages actually paid. This is the reason that our statistical study has been only of the salaries paid by the employers, with references to the decrees themselves in order to establish the necessary comparisons.

The statistics that we are presenting in this Bulletin come from figures submitted to the Quebec
City and District Wholesale Food Trade Parity Committee by the employers subject to the decrees regulating this category of business. In the employers' reports, we have found all the desired information for a quantitative analysis of the weekly salaries of all the employees working in this type of business. We have therefore at the beginning established a frequency distribution showing the fluctuations of salary for the period 19451949. Our statistical observation shows for a period of five years the salaries at a given time (month of February) during the corresponding year.

Following this, we have compared the arithmetic average of salaries, for each year, in terms of index numbers with the Federal cost of living index. The choice of this Federal index is only justified by the desire to determine an approximation of the real salaries. 